\title{
Small cell lung cancer
}

INSERM

\section{Source}

INSERM. (1999). Orphanet: an online rare disease and orphan drug data base. Small cell lung cancer. ORPHA:70573

Small cell lung cancer (SCLC) is a highly aggressive malignant neoplasm, accounting for 10-15\% of lung cancer cases, characterized byrapid growth, and early metastasis. SCLC usually manifests as a large hilar mass with bulky mediastinal lymphadenopathy presenting clinically with chest pain, persistent cough, dyspnea, wheezing, hoarseness, hemoptysis, loss of appetite, weight loss, and neurological and endocrine paraneoplastic syndromes. SCLC is primarily reported in elderly people with a history of long-term tobacco exposure. 